\title{
Effect of irrigation frequency and NPK level on yield efficiency, resource use and harvest index of indigenous wild cucumber Cucumis africanus
}

\author{
R. J. Nkgapele \& M. S. Mphosi \\ Limpopo Agro-food Technology Station, School of Agriculture and \\ Environmental Sciences, University of Limpopo, Republic of South Africa
}

\begin{abstract}
In South African traditional medicine the roots, stems, leaves or fruit of wild cucumber, Cucumis africanus, are used as an emetic, purgative or enema for various ailments. The fresh young leaves are eaten as a pot herb by many rural people. A study was conducted to show the effects of irrigation frequency and NPK fertilizer application rate on leaf yield characters, harvest index and resource use efficiencies of $C$. africanus. The experiment was laid out in a splitplot design arrangement and replicated three times. Three irrigation frequencies, namely, 2, 4 and 6 days, were assigned as main plots and Nitrogen, Phosphorus and Potassium (NPK) application rates of $0 \mathrm{Kg}^{\mathrm{NPK}} \mathrm{ha}^{-1}, 60-40-20 \mathrm{~kg} \mathrm{NPK} \mathrm{ha}{ }^{-1}$, 120-80-40 kg NPK ha ${ }^{-1}$ and 180-120-60 kg NPK ha' ${ }^{-1}$ were sub-plots. EYR, YER, AHI and SHI were significantly $(\mathrm{P}<0.05)$ higher in the intermediate treatment of four day irrigation frequency and 120-80-60 kg NPK ha ${ }^{-1}$, while WUE and NUE were pronounced in the six day irrigation frequency and 180$120-60 \mathrm{~kg}$ NPK ha ${ }^{-1}$. WUE was significantly $(\mathrm{P}<0.05)$ affected by both irrigation frequency and the interaction between irrigation frequency and NPK application rate, while NUE responded to NPK level only.

Keywords: edible yield rate, yield efficiency rate, harvest index, water use efficiency.
\end{abstract}




\section{Introduction}

In South African traditional medicine the roots, stems, leaves or fruit of wild cucumber, Cucumis africanus, are used as an emetic, purgative or enema for various ailments. The fresh young leaves are eaten as a pot herb by many rural people. Since antiquity to date, indigenous wild useful plants have been handled by human societies for food and ethno-botanical purposes. While, the smallholder farmer societies still continue to profess such livelihoods, the agricultural community did not exploit the use of non-cultivated resources. In recent times, most human plant food is based on rather limited number of crops, 12 crops contribute more than $85-90 \%$ of world's caloric intake [1]. However, it is clear that in many parts of the world, especially in rural peripheries of developing regions, the use of wild plants is not negligible [2] and warrants greater need for research on crop responses to conventional agronomic methods of production such as integrated irrigation and fertilizer application [3].

Irrigation and NPK fertilizer combinations play a vital role in enhancing crop yields [1]. Agronomic management practices of integrated irrigation water and NPK application increases leaf area development and improves leaf area duration (LAD) after flowering and increases overall crop assimilation, thus contributing to increased seed yield $[4 ; 5]$. Other workers [6] concluded that irrigation and NPK fertilizer increases yield by influencing a variety of growth parameters such as the number of branches per plant, the number of pods per plant, the total plant weight, and leaf area index (LAI). Agricultural research studies on crop agronomic and diet surveys tend to ignore wild plants in comparison to cultivated ones, and this is a methodological deficiency [7].

The agronomic efficiency of resource inputs is the amount of increase in yield of harvestable product per $\mathrm{kg}$ of applied resource inputs where high yields are obtained [8]. In smallholder farming systems, increase in yield could best be achieved by adopting high potential traditional leafy/ethno-botanical crops, and supplementing soils with required plant nutrients and irrigation water.

Critical to sustainable production of indigenous multi-purpose leafy-vegetable and ethno-botanical crops will be augmenting vegetative harvest yields and cropping area. Consequently, important statistical information for leafy and ethno-botanical crops is on edible yield rate (EYR) and yield efficiency rate (YER). EYR is the rate of edible (leaf) dry biomass produced by a crop per unit growth area $\left(\mathrm{g} \mathrm{m}^{-2}\right.$ day $\left.^{-1}\right)$. YER is expressed in units of $g$ dry weight (DW) edible biomass $/ \mathrm{m}^{2}$ per day per $\mathrm{g}$ DW non-edible biomass.

\section{Materials and methods}

The experiment was conducted at Horticultural Research Facility of University of Limpopo, Limpopo Province, South Africa (23 $\left.{ }^{\circ} 53^{\prime} 10^{\prime \prime} \mathrm{S} ; 2^{\circ} 44^{\prime} 15^{\prime \prime} \mathrm{E}\right)$ during the 2009-2010 summer growing season. Ambient day/night temperatures averaged $28 / 21^{\circ} \mathrm{C}$, with maximum temperatures controlled using thermostatically-activated fans. 
The experiment was laid out in a split-plot design arrangement and replicated five times. Three irrigation frequencies, namely, 2, 4 and 6 days, were accorded as main plots. During each irrigation frequency, $1000 \mathrm{ml}$ tap-water was applied per pot. Irrigation water application treatments were applied seven days after transplanting. Sub-plot treatments were accorded to varying NPK application rates which were $0 \mathrm{Kg}$ NPK ha ${ }^{-1}, 60-40-20 \mathrm{~kg} \mathrm{NPK} \mathrm{ha}^{-1}, 120-80-40 \mathrm{~kg}$ NPK ha ${ }^{-1}$ and 180-120-60 kg NPK ha-1.

Seedlings were raised in seedling trays using thirty-cm-diameter plastic pots, filled with $10 \mathrm{~L}$ steam-pasteurised sand and Hygromix $(3: 1 \mathrm{v} / \mathrm{v})$, which were placed on greenhouse benches at $0.5 \mathrm{~m}$ inter-row and $0.6 \mathrm{~m}$ intra-row spacing. Uniform three-week-old Cucumis africanus seedlings were transplanted to the pots one day after irrigating the growing medium to field capacity. The first experiment was harvested at 40 days after transplanting (DAT) and the second at 60 DAT. NPK fertilizer $(3: 2: 1)$ was given in split doses. First dose was applied at transplanting of seedlings into $30 \mathrm{~cm}$ plastic pots, while the remaining dose was applied 20 days after the first dose.

Harvesting was done at 40 days after transplanting (DAT) and data was recorded for water use efficiency (WUE), nutrient use efficiency (NUE), Edible yield rate (EYR), yield efficiency rate (YER), apparent harvest index (APHI); shoot harvest index (SHI), and Water and NPK use efficiencies were computed for the experiments.

The following formula was used to compute WUE:

$$
\text { WUE }=\frac{\text { crop biomass yield }\left(\mathrm{kg} \mathrm{ha}^{-1}\right)}{\mathrm{TWU}\left(\mathrm{m}^{3} \mathrm{~m}^{-2}\right)}
$$

where, TWU is the total water applied.

The classical method for evaluating fertilizer use efficiency was determined by the following equation:

$$
\operatorname{NUE}(g \text { biomass } \backslash g \mathrm{~N})=\frac{\mathrm{Y}_{\mathrm{N}}-\mathrm{Y}_{0}}{\mathrm{~F}_{\mathrm{N}}}
$$

where, $Y_{N}$ and $Y_{0}$ are crop biomass yields $\left(\mathrm{kg} \mathrm{ha}^{-1}\right)$ of fertilized crop and in the control treatment, respectively, $N$ refers to particular nutrient being computed and $F_{N}$ is the amount of fertilizer applied $\left(\mathrm{kg} \mathrm{ha}^{-1}\right)$.

Edible yield rate (EYR), yield efficiency rate, and apparent (AHI) and structural (SHI) harvest indexes were computed using the following expressions:

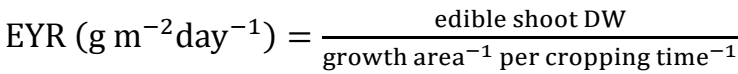

$$
\begin{aligned}
& \operatorname{YER}\left(\mathrm{g} \mathrm{m}^{-2} \text { day }^{-1} \mathrm{~g}^{-1}\right)=\frac{\text { EYR }}{\text { nonedible shoot } \mathrm{W}^{-1}} \\
& \mathrm{AHI}=\frac{\text { edible leaf } \mathrm{W}}{\text { total shoot } \mathrm{W}}
\end{aligned}
$$




$$
\mathrm{SHI}=\frac{\text { edible leaf } \mathrm{W}}{\text { total biomass DW-edible leaf W }}
$$

where, $\mathrm{W}$ is biomass fresh or dry weight.

The data of all the above mentioned were individually subjected to the analysis of variance techniques using Statistix 8.1 software (Statistix, Analytical Software, Statistix; Tallahassee, FL, USA, 1985-2003). Mean comparisons were done using least significance difference (LSD) at 0.05 level of probability $[9,10]$. When treatments were significant sum of squares were partitioned to determine the percentage contribution of source of variation to the total treatment variation [11].

\section{Results}

\subsection{Edible yield rate and yield efficiency rate}

EYR and YER showed significant $(\mathrm{P}<0.05)$ variations in response to irrigation frequency and NPK fertilizer application rate treatments (Table 1). 30\% and 39\% of EYR and YER total treatment variation was contributed to by the interaction between NPK application rate and irrigation frequency, respectively. The highest EYR and YER was 83 and $80 \%$ higher than lowest, respectively (Table 2).

Table 1: Analysis of variance for efficiency yield rate (EYR) and yield efficiency rate (YER) of Cucumis myriocarpus as affected by irrigation frequency and NPK application rate during the 2009/10 summer growing season.

\begin{tabular}{|l|l|l|l|l|l|}
\hline $\begin{array}{l}\text { Source of } \\
\text { variation }\end{array}$ & \multirow{2}{*}{ Df } & EYR & YER \\
\cline { 3 - 6 } & & SS & \% & SS & \% \\
\hline Replicate $(\mathrm{A})$ & 2 & 653.800 & 1.420 & 0.478 & 8.470 \\
\hline Irrigation $(\mathrm{B})$ & 2 & 1284.60 & $2.790 \mathrm{~ns}$ & 0.508 & 9.000 \\
\hline Error $(\mathrm{A} * \mathrm{~B})$ & 4 & 7821.10 & 17.01 & 0.234 & 4.150 \\
\hline NPK rate $(\mathrm{C})$ & 3 & 3060.40 & $6.660 \mathrm{~ns}$ & 1.178 & $20.88^{* *}$ \\
\hline $\mathrm{B} * \mathrm{C}$ & 6 & 18051.0 & $39.27 * *$ & 1.696 & $30.05 * *$ \\
\hline Error $\left(\mathrm{A}^{*} \mathrm{~B} * \mathrm{C}\right)$ & 18 & 15099.3 & 32.85 & 1.549 & 27.45 \\
\hline Total & 35 & 45970.3 & 100.0 & 5.643 & 100.0 \\
\hline
\end{tabular}

***Significant $(\mathrm{P}<0.01)$, **Significant $(\mathrm{P}<0.05), \mathrm{Df}=$ degree of freedom, $\mathrm{SS}=$ sum of squares, ns=non-significant.

\subsection{Water and nutrient use efficiency}

The highest water and NPK use efficiency were 86 and 76\% higher than lowest use efficiency among the treatment mixtures, respectively (Table 2). Water and nutrient $(\mathrm{NPK})$ use efficiency exhibited highly significant $(\mathrm{P}<0.01)$ differences as a response to the irrigation frequency treatment which contributed 61 and $32 \%$ of the treatment variation respectively. On the other hand, NPK use efficiency 
Table 2: $\quad$ Yield and resource use efficiencies of Cucumis africanus in response to irrigation frequency and NPK application rate during the 2009/10 growing season.

\begin{tabular}{|l|l|l|l|l|l|}
\hline \multirow{2}{*}{$\begin{array}{c}\text { Interval } \\
(\text { days })\end{array}$} & \multirow{2}{*}{$\begin{array}{l}\text { NPK rate } \\
\left(\mathrm{kg} \mathrm{ha}^{-1}\right)\end{array}$} & \multicolumn{2}{|c|}{ Yield efficiency } & \multicolumn{2}{l|}{ Resource use efficiency } \\
\cline { 3 - 6 } & 0 & EYR & YER & WUE & NUE \\
\hline 2 & 0 & $0.99 \mathrm{abc}$ & $74.07 \mathrm{ab}$ & $0.041 \mathrm{e}$ & - \\
\hline & $60-40-20$ & $0.69 \mathrm{bcde}$ & $52.78 \mathrm{ab}$ & $0.049 \mathrm{e}$ & $0.320 \mathrm{bc}$ \\
\hline & $120-80-40$ & $0.80 \mathrm{abcd}$ & $32.10 \mathrm{~b}$ & $0.057 \mathrm{e}$ & $0.294 \mathrm{c}$ \\
\hline & $180-120-60$ & $0.76 \mathrm{abcd}$ & $32.84 \mathrm{~b}$ & $0.063 \mathrm{e}$ & $0.267 \mathrm{bc}$ \\
\hline 4 & 0 & $0.58 \mathrm{cde}$ & $19.86 \mathrm{~b}$ & $0.203 \mathrm{bcd}$ & - \\
\hline & $60-40-20$ & $0.21 \mathrm{e}$ & $45.68 \mathrm{~b}$ & $0.130 \mathrm{de}$ & $0.793 \mathrm{abc}$ \\
\hline & $120-80-40$ & $1.83 \mathrm{a}$ & $88.74 \mathrm{a}$ & $0.153 \mathrm{cde}$ & $0.541 \mathrm{bc}$ \\
\hline & $180-120-60$ & $0.43 \mathrm{de}$ & $24.44 \mathrm{~b}$ & $0.125 \mathrm{de}$ & $0.331 \mathrm{bc}$ \\
\hline 6 & 0 & $0.54 \mathrm{cde}$ & $61.90 \mathrm{ab}$ & $0.139 \mathrm{de}$ & - \\
\hline & $60-40-20$ & $1.13 \mathrm{ab}$ & $30.42 \mathrm{~b}$ & $0.474 \mathrm{abc}$ & $1.225 \mathrm{a}$ \\
\hline & $120-80-40$ & $1.21 \mathrm{a}$ & $29.71 \mathrm{~b}$ & $0.335 \mathrm{a}$ & $0.839 \mathrm{ab}$ \\
\hline & $180-120-60$ & $0.69 \mathrm{bcde}$ & $24.44 \mathrm{~b}$ & $0.296 \mathrm{ab}$ & $0.463 \mathrm{bc}$ \\
\hline
\end{tabular}

Column means with the same letter were not different at $5 \%$ level according to the least significant difference test. $\mathrm{ns}=$ non-significant.

Table 3: Analysis of variance for nutrient and water use efficiencies of Cucumis myriocarpus as affected by irrigation frequency and NPK application rate during the 2009/10 summer growing season.

\begin{tabular}{|c|c|c|c|c|c|}
\hline \multirow{2}{*}{$\begin{array}{l}\text { Source of } \\
\text { variation }\end{array}$} & \multirow[t]{2}{*}{ Df } & \multicolumn{2}{|l|}{ WUE } & \multicolumn{2}{|l|}{ NUE } \\
\hline & & SS & $\%$ & SS & $\%$ \\
\hline Replicate (A) & 2 & 0.004 & 0.96 & 0.217 & 5.30 \\
\hline Irrigation (B) & 2 & 0.254 & $60.91 * * *$ & 1.309 & $31.97 * * *$ \\
\hline Error $(A * B)$ & 4 & 0.037 & 8.87 & 0.764 & 18.66 \\
\hline NPK rate $(C)$ & 3 & 0.011 & 2.64 & 0.778 & 19.00 \\
\hline$B * C$ & 6 & 0.065 & $15.59 * *$ & 0.415 & 10.13 \\
\hline Error $\left(A^{*} B^{*} \mathrm{C}\right)$ & 18 & 0.046 & 11.03 & 0.611 & 14.92 \\
\hline Total & 35 & 0.417 & 100 & 4.095 & 100 \\
\hline
\end{tabular}

$* * *$ Significant $(\mathrm{P}<0.01), * *$ Significant $(\mathrm{P}<0.05), \mathrm{Df}=$ degree of freedom, $\mathrm{SS}=$ sum of squares, ns=non-significant.

was also affected significantly $(\mathrm{P}<0.05)$ by irrigation frequency which contributed $32 \%$ to total treatment variation (Table 3 ).

\subsection{Apparent and structural harvest index}

Significant $(\mathrm{P}<0.05)$ differences in AHI and SHI were observed as a result of the interaction between irrigation frequency and the rate of NPK fertilizer application (Table 4).Interaction between irrigation application frequency and NPK application accounted for 25 and $37 \%$ of the total variation for AHI and SHI, respectively. NPK fertilizer application rate accounted for $13 \%$ of treatment 
variation of AHI, while SHI was non-significant (Table 4). The highest harvest index was respectively 67.7 and 56.6\% higher than lowest index in AHI and SHI (Table 5).

Table 4: Analysis of variance for apparent and structural harvest indexes of Cucumis africanus as affected by irrigation frequency and NPK application rate during the 2009/10 summer growing season.

\begin{tabular}{|c|c|c|c|c|c|}
\hline \multirow{2}{*}{$\begin{array}{l}\text { Source of } \\
\text { variation }\end{array}$} & \multirow[t]{2}{*}{ Df } & \multicolumn{2}{|c|}{ Apparent HI } & \multicolumn{2}{|c|}{ Structural HI } \\
\hline & & SS & $\%$ & SS & $\%$ \\
\hline Replicate (A) & 2 & 167.11 & 4.41 & 210.0 & 1.51 \\
\hline Irrigation (B) & 2 & 1119.6 & $29.55 \mathrm{~ns}$ & 2174 & $15.67 \mathrm{~ns}$ \\
\hline Error $(\mathrm{A} * \mathrm{~B})$ & 4 & 456.29 & 12.04 & 1571 & 11.32 \\
\hline NPK rate $(\mathrm{C})$ & 3 & 482.47 & $12.73 * * *$ & 563.4 & $4.06 \mathrm{~ns}$ \\
\hline $\mathrm{B} * \mathrm{C}$ & 6 & 943.68 & $24.91 * * *$ & 5159 & $37.18 * * *$ \\
\hline Error $\left(\mathrm{A}^{*} \mathrm{~B} * \mathrm{C}\right)$ & 18 & 619.75 & 16.36 & 4199 & 30.26 \\
\hline Total & 35 & 3788.87 & 100 & 13877 & 100 \\
\hline
\end{tabular}

*** Significant $(\mathrm{P}<0.01)$, ** Significant $(\mathrm{P}<0.05), \mathrm{Df}=$ degree of freedom, $\mathrm{SS}=$ sum of squares, ns=non-significant.

Table 5: $\quad$ Harvest indexes (HI) of Cucumis africanus as affected by irrigation frequency and NPK application rate at during the 2009/10 growing season.

\begin{tabular}{|l|l|l|l|}
\hline \multirow{2}{*}{$\begin{array}{l}\text { Interval } \\
\text { (days) }\end{array}$} & \multirow{2}{*}{$\begin{array}{l}\text { NPK rate } \\
\left(\mathrm{kg} \mathrm{ha}^{-1}\right)\end{array}$} & \multicolumn{2}{|c|}{ HI $(\%)$} \\
\cline { 3 - 4 } 2 & 0 & Apparent & Structural \\
\hline & $60-40-20$ & $39.09 \mathrm{a}$ & $80.88 \mathrm{ab}$ \\
\hline & $120-80-40$ & $36.32 \mathrm{a}$ & $65.56 \mathrm{ab}$ \\
\hline & $180-120-60$ & $32.32 \mathrm{ab}$ & $65.09 \mathrm{abc}$ \\
\hline 4 & 0 & $19.16 \mathrm{bc}$ & $37.15 \mathrm{c}$ \\
\hline & $60-40-20$ & $12.75 \mathrm{c}$ & $36.29 \mathrm{c}$ \\
\hline & $120-80-40$ & $39.47 \mathrm{a}$ & $83.54 \mathrm{a}$ \\
\hline & $180-120-60$ & $20.35 \mathrm{bc}$ & $53.73 \mathrm{bc}$ \\
\hline 6 & 0 & $35.19 \mathrm{ab}$ & $74.12 \mathrm{ab}$ \\
\hline & $60-40-20$ & $35.39 \mathrm{a}$ & $64.39 \mathrm{abc}$ \\
\hline & $120-80-40$ & $32.61 \mathrm{ab}$ & $54.10 \mathrm{abc}$ \\
\hline & $180-120-60$ & $25.80 \mathrm{abc}$ & $55.19 \mathrm{abc}$ \\
\hline
\end{tabular}

Column means with the same letter were not different at $5 \%$ level according to the least significant difference test.

\section{Discussion}

Traditional harvest practices of different cultures in South Africa demonstrate that multiple parts of Cucumis africanus plant are edible, either as a leafy vegetable or used as ethno-botanicals. EYR, YER and HIs (apparent and 
structural) are important crop statistic for controlled environments for crop production (e.g. greenhouses, tunnels, etc.), because they give an indication of how much harvest time, cropping area and non-edible crop residue can be minimized. Significant $(P<0.05)$ responses of EYR, YER and HIs were observed as a result of varying irrigation frequencies and NPK fertilizer application rate (Tables 1, 3 and 4).

Four day frequency x 120-60-30 NPK rate treatment produced higher EYR, AHI, SHI and YER which were correspondingly 29, 35, 60 and 90\% higher than average across all the treatments. These results support work by Stefanelli et al. [12] that moderate application rates of NPK fertilizer produces good vegetable yield characters, whereas high rates produces imbalances by promoting more vegetative components compromising other parts and low rate leads to poor quality and/or crop failure. Thus, intermediate irrigation and NPK applications can assist in improving the production of Cucumis africanus under greenhouse regimes.

The vegetative efficiency of Cucumis africanus is critical to sustainable production of the multi-purpose crop plant. Ohler and Mitchell [13] suggested that higher EYR, YER and HIs indicates good edible leaf yield or shoot products that could be used to add nutritional value and fibre to diets. Protein of leaves and other vegetative plant components provide amino acids complementarities to that of cereal grains. To achieve success, good agronomic practice such weed and pest control, low amelioration activities, irrigation scheduling, split fertilizer application, etc. must also be taken into account.

Water and NPK use efficiency ranged from 0.294 to 1.225 and 0.05 to 0.34 respectively. The highest water and NPK use efficiency were observed in irrigation frequency of 6 days and NPK rates of 120 and $60 \mathrm{~kg} \mathrm{NPK} \mathrm{ha}{ }^{-1}$, respectively. These results agrees with the finding by several [5] in canola, [14] in glory lily, who found that $120 \mathrm{~kg} \mathrm{ha}^{-1}$ nutrient application level produced maximum values for all these traits as compared to minimum in control. Khan et al. [15]) also concluded that irrigation frequency of 5 days was the better irrigation frequency as compared to other treatment in a study with onion varieties. The study results confirm that Cucumis africanus can be successfully produced by smallholder farmers who reside mainly in areas where water is a scarce resource. The result is attributed to the fact that Cucumis africanus is an indigenous crop plant that grows in harsh wild conditions which means that it has some degree of inert drought tolerance and stress survival mechanisms.

\section{Conclusions}

The study results revealed that the intermediate category of 4 days interval and $120-80-40 \mathrm{~kg}$ NPK rate treatment produced better results $(\mathrm{P}<0.05)$ in most of the parameters studied. The values of EYR, YER, AHI and SHI obtained in the study confirms that Cucumis africanus can be grown successfully for the production vegetative and root components to sustain its use as leafy vegetable and ethno-botanicals to improve smallholder farmer livelihoods. In addition, the lengthy irrigation frequency of six day interval and moderate nutrient application 
rate were efficient in water and NPK use, thereby confirming that Cucumis africanus can be grown under conditions of limited water supplies and minimal nutrient inputs.

\section{References}

[1] FAO. Fertilizer use by crops in South Africa. FAO, Rome, pp. 16-21, 2005.

[2] Jansen van Rensburg, W.S., van Averbeke, W., Slabbert, R., Faber, M., van Jaarsveld, P., van Heerden, I., Wenhold, F., and Oelofse, A. African leafy vegetables in South Africa. Water SA, 33 (3), 317-326, 2007.

[3] Nkgapele, R.J., Mphosi M.S., and Mashela, P.W. Effect of irrigation amount and frequency on phenology, vine length and biomass partitioning of wild cucumber (Cucumis africanus) and wild watermelon (Cucumis africanus). Water Resource Management VI, WIT press, Wessex Institute of Technology, UK, pp. 557-564, 2011.

[4] Gardner, F.P., Pearce, R.B. and Mitchell, R.L. Physiology of crop plants. Iowa state university press: Ames, pp. 187-209, 1985.

[5] Cheema, M.A., Saleem, M.F., Muhammad, N., Wahid, M.A. and Baber B.H. Impact of rate and timing of nitrogen application on yield and quality of canola (Brassica napus L.). Pakistan Journal of Botany, 42(3), pp. 17231731, 2011.

[6] Al-Barrak, K.M. Irrigation frequency and Nitrogen Level Effects on Growth and Yield of Canola (Brassica napus L.). Scientific Journal of King Faisal University, Basic and Applied Science, 7 (1), pp. 87-103, 2006.

[7] Nkgapele, R.J., Mphosi, M.S., and Mashela P.W. Comparing Cucumis africanus and Cucumis africanus using classical growth analysis tool under five irrigation frequencies. Water Resource Management VI, WIT press, Wessex Institute of Technology, UK, pp. 565-570, 2011.

[8] Okorogbona, A.O.M., Van Averbeke, W., Ramusandiwa, T.D. Growth and yield response of Chinese cabbage (Brassica rapa L. subsp. chinensis) as affected by nutrient availability in air-dried and pulverized different types of animal manure using low biological activity soil. World Journal of Agricultural Science, 7 (1), pp. 1-12, 2011.

[9] Gomez K.A. and Gomez A.A. Statistical procedures for agricultural research $2^{\text {nd }}$ ed. John Wiley \& Sons, New York., pp. 146-184, 1984.

[10] Kuehl R.O. Design of experiments: statistical principles of research design and analysis $2^{\text {nd }}$ ed. Duxbury press, New York., pp 173-184, 2000.

[11] Little, T.M. and Hills, F.J. Statistical methods in agricultural research, University of California, California, USA, pp. 350, 1981.

[12] Stefanelli, D., Goodwin, I. and Jones R. Minimal nitrogen and water use in horticulture: Effects on quality and content of selected nutrients. Food Research International, 43, pp. 1833-1843, 2010.

[13] Ohler, T.A. and Mitchell C.A. Identifying yield-optimizing environments for two cowpea breeding lines by manipulating photoperiod and harvest scenario. Journal of American Society of Horticultural Science, 121(3), pp. 576-581, 1996. 
[14] Deivasigamani, S. and Thanunathan K. Integrated nutrient management practices for Glory lily (Gloriosa superba L.). Journal of Medicinal and Aromatic Plants, 2(1), pp. 6-9, 2011.

[15] Khan, M.H., Imran, M. and Chattha T.H. Effect of irrigation frequencies on growth and yield of onion varieties Swat-1 and Phulkara. Journal of Applied Science Research, 1(2), pp. 112-116, 2005. 